\title{
Grundtvig som kontextuell teolog
}

\author{
Af Anders Holmberg
}

\section{Inledning ${ }^{1}$}

För en svensk som kommer till Danmark är det tydligt att Grundtvig (förkortas här $\mathrm{G}$ ) och hans verk har påverkat landet på en mängd olika sätt. I Sverige finns det inte någon klar parallell och inte heller någon historisk gestalt som har haft en till närmelse lika stor inverkan på samhället på så många olika plan som G. Därför blir det intressant att se närmare på hur detta har gått till. Ett sätt att studera detta är att försöka tränga in i Grundtvigs teologiska tänkande för att se om det kan finnas en förklaring där. Om det kan vara fallet att $G$ i sin teologi på ett unikt sätt har lyckats förena den kristna tron med den folkliga danska kulturen så att de tu har förenats till en för många relevant livssyn - och därmed denna påverkan har kunnat komma till stånd.

När sedan professor Theodor Jørgensen kopplade samman begreppet kontextuell teologi ${ }^{2}$ med Grundtvig insåg jag att detta var något som borde studeras närmare.

Min hypotes var därmed att Grundtvigs teologiska tänkande på ett unikt sätt stämde med situationen i det danska samhället på 1800-talet och att detta var förklaringen på hur Grundtvig kunde få den betydelse och påverkan på det sätt han gjort. Det intressanta för mig var dock inte själva slutresultatet, Grundtvigs »färdiga« teologi utan att få syn på metoden, på vilket sätt utformningen av teologin skedde.

Kanske kunde vi som lever på 1990-talet kunna dra lärdomar av Grundtvig för att kunna uttrycka vår tro på ett sätt som är relevant $\mathrm{i}$ vår egen tid?

I modern teologi är ett aktuellt begrepp »kontextuell teologi«. I Tros- och Livsåskådningsforskningen i Uppsala och Lund har detta begrepp under de senaste åren kommit att allt mer stå i centrum och en rad undersökningar har skett, inte minst utifrån den förra professom i Lund Per Frostins arbeten. ${ }^{3}$

I den svenska universitetsteologin har influenser från den engelskspråkiga världen gjort sig gällande långt mer än vad som skett i Danmark, dessutom har under senare år allt fler teologer intresserat sig för det teologiska tänkande som skett i den s.k. tredje världen. I båda dessa sfärer används begreppet »kontextuell teologi«. 
I denna artikel görs först en redogörelse för vad detta begrepp innebär utifrån boken »Models of Contextual Theology« av Stephen B. Bevans. ${ }^{4}$

Därefter vill jag föreslå ett sätt att se Grundtvigs teologiska tänkande som det tar sig uttryck i »Den christelige Børnelardom «" (förkortas här DCB) som kontextuell teologi.

\section{Kontextuell teologi}

I det följande avsnittet görs ett försök att ringa in begreppet kontextuell teologi, inledningsvis kan sägas att begreppet hos Bevans ses som en rad olika metoder att göra teologi snarare än en företeelse som har en specifik innehållslig karaktär. Det grundläggande är att den kristna tron medvetet ställs i relation till den omgivande samtida kulturen i utformandet av teologin.

I min genomgång är det två grundfrågor som närmare studeras. Den ena gäller synen på kunskap om Gud, det vill säga hur ser man på problem kring uppenbarelse och bibel. Den andra frågan gäller synen på kulturen, hur man ser på den omgivande situationen, samhället och med dessa sammanhängande faktorer.

Det finns en mängd olika definitioner av kontextuell teologi, en av de bredaste definitionerna finner man hos Bevans. I sin bok visar han på fem olika sätt att göra kontextuell teologi. Grundförutsättningen är att en teolog medvetet tar i beaktande fyra olika faktorer då han eller hon skapar sin teologi. Bevans ger följande definition av kontextuell teologi:

»Contextual thelogy can be defined as a way of doing theology in which one takes into account: the spirit and the message of the gospel; the tradition of the Christian people; the culture in which one is theologizing; and social change in that culture, whether brought about by western technological processes or the grass-roots struggle for equality, justice and liberation " $^{6}$

De fyra faktorerna definieras på följande sätt:

a, Andan och budskapet $\mathrm{i}$ evangeliet kan definieras som innehållet i de bibliska skrifterna, det har visat sig hos Bevans att synen på 
skriften och på vad uppenbarelse innebär har stor betydelse och är skiftande i de olika modellerna. I vissa av modellerna definieras uppenbarelse som något inneboende i själva kulturen.

b, Det kristna folkets tradition innehåller hela kyrkans historia med avseende på utvecklingen av tänkande och kristen handling. Men också den tradition som nått fram till vår samtid och som finns som utövad religion i nuet.

c, Definition av kulturen i vilken man gör teologi kräver en kulturteori, centralt är att kultur här defineras brett - d.v.s. att bl.a. språk, mänskliga relationsformer, politik, ekonomi och relationer till andra kulturer finns med. Bevans vill själv ansluta sig till något som han kallar »an empirical notion of culture «. Denna uttrycker han på följande sätt: »a set of meanings and values that informs a way of life «. ${ }^{7}$ Det vill säga en uppsättning av uppfattningar om vad som är meningsfullt och värdefullt. Detta varierar stort mellan olika kulturella områden och därför kan man inte tala om en objektiv eller allomfattande kultur utan om många olika kulturer.

d, Synen på sociala förändringar i kulturen är avhängig av den syn på kultur man har, men här inbegrips såväl teknisk utveckling som folkets egen kamp för förändring av sin kultur. Bevans vill skilja mellan kulturen och förändringarna även om de hänger samman, för att kunna dra skiljelinjer mellan den typ av teologiserande som rör sig om att kartlägga traditionell kultur och den typ som har samhällsförändring som sitt centrum.

Snart visar det sig hos Bevans att de olika sätten att göra kontextuell teologi hänger samman med olika förståelse av de fyra faktorerna, särskilt vad gäller synen på kunskap om Gud d.v.s. uppenbarelse och synen på kulturen. Men även att de mest djupgående skillnaderna är av filosofisk och epistemologisk art. Det vill säga olika svar på frågor som: vad är kunskap? hur vet man om något är sant? teorier om kunskapsförmedling o.s.v.

Jag vill i fortsättningen mycket skissartat och förenklat gå igenom Bevans modeller för att använda dem som ett analysredskap när jag samtidigt söker finna ett svar på min dubbla problemställning:

Kan Grundtvigs teologi tolkas som en kontextuell teologi?

På vilket sätt gör han i sådana fall sin kontextuella teologi? 
Några synpunkter på Grundtvigs teologiska metod

Innan detta vill jag se på några forskares synpunkter angående Grundtvigs teologiska metod. Detta är av betydelse för att kunna bedöma huruvida det är möjligt att tolka Grundtvigs teologiska arbete som en kontextuell teologi.

Ett flertal forskare tar upp DCB i sina arbeten och några av dem kommenterar även metoden som $\mathrm{G}$ använder för att skapa sin teologi. Här vill jag ta upp tre av dem som kan vara av intresse.

\section{Harry Aronson}

En av dessa är Harry Aronson som i sin avhandling »Mänskligt och kristet « (Stockholm 1960) ser Gs kristendomstolkning som präglad av fornkyrkan och samtidigt innehållande »ett verksamt element från europeiskt filosofiskt tänkande« (s. 292-293). Detta sistnämnda element är något som Aronson kallar »den wolffianska tankeformen« och som går tillbaka på filosofen $\mathrm{C}$. Wolff och som $\mathrm{G}$ lärt under sin studietid i Köpenhamn. Från Wolff har G hämtat den s.k. motsatslagen. Jag går här inte djupare in $\mathrm{i}$ vad detta innebär utan konstaterar endast att enligt Aronson bygger $\mathrm{G}$ sin teologi både på traditionen, d.v.s. fornkyrkan, och samtida filosofiskt tänkande.

\section{Svend Bjerg}

Svend Bjerg har tolkat Gs teologi utifrån ett perspektiv grundat på narrativ teologi. I tidskriften »Kredsen« 1984 återfinns Bjergs artikel "Grundtvigs begreb om Teologi $i$ "Den christelige Børnelardom".

Bjerg hävdar där att Gs sätt att göra teologi i DCB bygger på Gs egna erfarenheter och att det närmast kan ses som av självbiografiskt slag. Gs förståelse av livet och den kristna tron bygger på Gs egna upplevelser och erfarenheter. Bjerg sammanfattar processen med följande ord: »Vejen går fra liv over ordene til lære, der igen kaster lys over livet.«(s.36) De livserfarenheter som formuleras i ord leder till utformandet av läran, vilken i sin tur används som tolkningsmall för nya livserfarenheter. Som stöd för sin uppfattning tar Bjerg den utformning DCB har fått. Bjerg uttrycker DCB:s struktur som att den 
»kredser tæt om centrale kristne livsoplevelser.« När G ska sammanfatta sin kristna tro så sker det nämligen inte på ett traditionellt sätt, d.v.s. strukturerat utifrån den Apostoliska trosbekännelsen. Istället kretsar den kring Gs kyrkliga tros-erfarenheter genom att $G$ tar upp dopgudstjänstens och nattvardsgudstjänstens olika delar, församlingens livstecken, äktenskapet, om det medfödda och det pånyttfödda människolivet, situationen i kyrkan etc. Denna struktur i Gs bild av den kristna tron leder till att det viktigaste är upplevelsen och erfarenheten av det gudomliga. Detta menar Bjerg leder också för $\mathrm{G}$ till att han inte anstränger sig för att ge bevis, erfarenheterna kommer själva att visa den kristne att läran är sann. »Det sørger livet for, når det viser sig at menigheden kan leve på den kristne erfaring. Dogmatikkens opgave er at tænke efter, hvordan man klart kan formulere erfaringer i ord, så den bedre kan tilegnes. Eftertanke skal dogmatikken præstere, ikke bevisførelse.«(s. 37) Själva livet med sina erfarenheter och framförallt det kristna livet med sina erfarenheter av livet med Gud kommer att visa om teologin har funnit ett sant uttryck för dessa erfarenheter. Teologin har alltså enbart att arbeta med att söka ett sant eller autentiskt uttryck för troserfarenheterna.

\section{Helge Grell}

Grundtvigforskaren Helge Grell skriver i boken »Skaberånd og folkeånd" (Köpenhamn 1988) att Gs teologi

»et langt stykke af vejen er ét med hans historiesyn. Men dette er begrundet i hans skabelsesteologi, som er fundamentet for hele hans værk, og som gør det sammenhængende og udeleligt.« (s. 317)

Grunden för Gs teologiska tänkande är enligt Grell alltså två storheter, hans historiesyn och hans skapelsesyn. Men dessa två är i hög grad sammanfallande hos $\mathrm{G}$, inte minst i Gs syn på den s.k. allmänna uppenbarelsen. G ser enligt Grell Guds skaparord verksamt i folkets historia, och därmed får historien och folkligheten en betydande påverkan på teologin, även om den människosyn som är grunden för G framförallt kan upptäckas i Jesu liv. Grell hävdar att den växelverkan som sker mellan det folkliga och det kristna innebär att 
mänsklighet, folklighet och kristendom knyts allt tätare tillsammans i Gs tänkande. Denna grund för Gs teologiska arbete gör att han tar i beaktande både den folkliga, allmänmänskliga, historiska situationen och det kristna, här uttryckt som Jesu liv, i sitt teologiserande. I mötet eller växelverkan mellan de två växer Gs teologi fram.

\section{Grundtvig som kontextuell teolog?}

I min genomgång av Gs teologi har jag funnit vissa drag som liknar delar i samtliga modeller för kontextuell teologi hos Bevans. Här vill jag redogöra för dessa explicit och därefter göra en bedömning av möjligheten att tolka $\mathrm{G}$ som kontextuell teolog.

Detta kommer jag att göra genom att sammanföra de två. Utifrån en analys av »Den christelige Børnelærdom « och några andra av Grundtvigs texter går jag igenom de fem modellerna för kontextuell teologi. Men innan denna genomgång vill jag här redovisa Gs hållning till Bevans fyra faktorer.

I min genomgång av Grundtvigs skrifter har jag kommit fram till att han säger mycket om de fyra faktorer som Bevans lyfter fram som de grundläggande för en teolog som vill göra en kontextuell teologi. Här gör jag en kort sammanfattning av Grundtvigs hållning till de fyra faktorerna.

\section{Skriften}

Bibelns funktion hos Grundtvig är mer av en upplysningsbok om det kristna livet än dess grund. Detta ger G möjligheten att ha en relativt fri hållning till bibeln.

\section{Den kristna traditionen}

Inom detta område finns Gs grund för kristendomen. Det är i den kristna församlingens bekännelse av sin tro som kyrkans och kristendomens identitet finns. ${ }^{8}$ Detta är därmed den punkt som för $G$ är mest orubblig och omöjlig att ifrågasätta eller att förändra om man fortfarande ska kunna tala om kristendom överhuvudtaget. 


\section{Kulturen}

Det som Bevans kallar kulturen vill jag främst identifiera med Gs tal om folkligheten. Den har en avgörande betydelse i Gs tankar, främst som en förutsättning för förståelse av grundläggande temata $\mathrm{i}$ den kristna tron, G ser folkligheten i termerna Folkminnet, Folkhoppet och Det folkliga bildspråket. ${ }^{9}$ Denna folklighet är för $\mathrm{G}$ något ytterst värdefullt och han hävdar ofta att den bör värnas eller skapas om den inte är för handen.

Gs syn på det folkliga som kulturen gör att en del av det som Bevans inbegriper i begreppet kultur faller utanför, som exempel kan ekonomiska förhållanden och produktionsförhållanden nämnas. G har också uttalade tankar om dessa men av utrymmesskäl har jag lämnat dem åsido.

\section{De sociala förändringarna}

G delade sin samtids utvecklingsoptimism och hade därmed en positiv syn på de historiska förändringarna, han verkade för en fredlig evolutionär utveckling av sitt land, bland annat för att undvika revolution. ${ }^{10}$

\section{Analysfrågor}

För att besvara min problemställning vill jag nu gå vidare och ställa Grundtvigmaterialet inför några analysfrågor i relation till alla de fem modellema för kontextuell teologi som Bevans beskriver. De fyra frågor jag ställer till materialet är följande:

1, Hur förhåller sig Gs syn på den kristna trons identitet till modellens syn? (dvs frågor som rör skriften och traditionen samt uppenbarelse)

2, Hur förhåller sig Gs syn på kulturen till modellens syn? (dvs frågor som rör kulturen och sociala förändringar).

3 , Hur förhåller sig Gs syn på relationen mellan kristen identitet och kultur till modellens syn?

4, Kan G tolkas som kontextuell teolog enligt denna modell? 


\section{Modell 1: Översättningsmodellen}

Denna modell karakteriseras av att skriften och traditionen är det centrala, dessa anses innehålla en kärna, ett överkulturellt innehåll som kan iklädas olika kulturella skal eller uttryckssätt. Kontextualiseringen sker då detta skal utformas i nära kontakt med en kulturell situation.

\section{Den kristna trons identitet}

Modellen utgår från att den kristna tron har en given identitet, vad exakt denna identitet innehåller är omstritt bland modellens förespråkare. Men att det finns ett innehållsligt, av Gud uppenbarat trosinnehåll som kännetecknar en autentisk kristen tro tillhör modellens förutsättningar.

Grundtvig har en klar och tydligt formulerad bestämning av sin syn på den kristna trons identitet. Den utgörs av den apostoliska trosbekännelsen bekänd av troende kristna vid dopet tillsammans med instiftelseorden vid dop och nattvard. Denna grund vill jag här kalla »det levande ordet«. G betonar även att han ser denna grund som given av Kristus själv och bevarad genom kyrkans historia. ${ }^{11}$

Detta skulle kunna tolkas som en överensstämmelse med översättningsmodellens tal om det givna oföränderliga innehållet. Men det finns faktorer som talar emot denna tolkning. En av dessa faktorer är sättet på vilket $G$ kommer fram till sin trosgrund. Detta sker i en reaktion mot den framväxande bibelkritiken som enligt $G$ gjort bibelns auktoritet osäker, men också i en påverkan från den filosofiska romantiken bl.a. med sin betoning av historien. $G$ har självfallet även egna originella tankar i sin syn på »det levande ordet « som kan tolkas som ett slags kerygmatisk kyrkosyn. Gs teologi grundas även i hans egna personliga erfarenheter vilket han bl.a. skildrar i sitt sökande efter en trosgrund som en djup längtan eller ett inre behov. ${ }^{12}$ Dessa faktorer talar mot översättningsmodellens syn på den kristna trons identitet som något överkulturellt och givet som kan finnas efter att budskapet s.a.s. klätts av sin kulturella kostym.

$\mathrm{G}$ har förutom detta även en utbyggd lära om den sk. allmänna uppenbarelsen, det är utifrån den kunskap man får om Gud genom allmänmänskligt åtkomliga erfarenheter människan kan förstå vad 
»det levande ordet « innebär. Detta sker bland annat genom myterna, historien och de nära mänskliga relationerna.

Allt detta sammantaget betyder att Gs syn på den kristna identiteten inte kan sägas stå i överensstämmelse med översättningsmodellen.

\section{Kulturen och relationen mellan kristen tro och kultur}

I denna modell ses kulturen som något slags yttre form, dessutom innehåller varje kultur motsvarande uttryck som andra kulturer. Även $\mathrm{G}$ betonar att ett folk $\mathrm{i}$ sin egen kultur och språk måste ha vissa föreställningar för att kunna förstå det kristna budskapet.

$\mathrm{G}$ hävdar att den goda folkligheten antingen måste existera eller skapas för att budskapet ska kunna förstås. Men just i Gs tankar om det folkliga i relation till det kristna finns enligt min mening den avgörande skillnaden mot denna modells syn på kulturen. Enligt min tolkning av G har det folkliga en större inverkan på både form och innehåll i det kristna budskapet än vad som översättningsmodellen visar. Även detta kan kopplas samman med Gs syn på den allmänna uppenbarelsen, för $\mathrm{G}$ finns det även i kulturen drag av gudomlig uppenbarelse i och med att den är skapad av Gud och utformad av människor som är bärare av Guds avbild. Detta betyder att kulturen knappast kan ses som ett neutralt yttre skal utan istället i sig bär viktiga delar av gudskunskap. Den växelverkan som råder mellan folkligt och kristet i Gs teologi innebär alltså en betydligt större ömsesidig påverkan på båda sidorna än översättningsmodellen hävdar.

\section{$\ddot{A r}$ Grundtvigs teologi kontextuell enligt denna modell?}

Trots de grundläggande skillnaderna kan man hos $G$ finna vissa drag av denna modells metod. Detta finns främst i psalmer och predikningar hos G. I psalmen »Tag det sorte Kors fra Graven!« kan vi se hur $\mathrm{G}$ i sin skildring av den bibliska berättelsen om mötet mellan den uppståndne Kristus och Maria Magdalena förflyttar sig från Palestina till våren i Danmark. ${ }^{13}$ Detta kan tolkas som en form av kontextualisering som liknar översättningsmodellen. Den i bibeln givna berättelsens innebörd placeras in i Gs samtida danska miljö. G är alltså inte 
främmande för att använda sig av denna metod även om hans teologi på ett flertal sätt går utöver denna modell för kontextualisering.

\section{Modell 2: Den antropologiska modellen}

I denna modell finns det mycket tydliga likheter med Gs teologi men även vissa skillnader. Modellen har människan i kulturen som sitt centrum. Man menar här att Guds uppenbarelse finns i själva kulturen. Det gäller att söka rätt på den där, uppenbarelsen kan kännas igen genom att forskaren har rapporter från tidigare genomsökningar i kulturen- dvs i skriften och traditionen. Kontextualiseringen sker då man med hjälp av vetenskapliga metoder som antropologi, sociologi eller lingvistik genomsöker en kultur för att finna uppenbarelsen. Då de drag funnits som är grundläggande i kulturen och har avtäckts med hjälp av skriften och traditionen som inspiration från tidigare sökande har kontextualiseringen funnit sitt uttryck.

\section{Den kristna trons identitet och kulturen}

I denna modell är det inte möjligt att skilja mellan den kristna identiteten och kulturen och därefter att se på relationen mellan de två. Därför väljer jag här att se på alla mina tre analysfrågor $\mathrm{i}$ ett sammanhang.

Modellens syn på den kristna trons identitet är betydligt mer komplex och mångfaldig än den föregående modellens syn. Identiteten består inte av ett givet budskap genom skrift eller tradition, utan istället i kulturella skapelsegivna förhållanden. Det är svårt att kort formulera den kristna trons identitet eftersom den ser mycket olika ut i olika kulturer, men grundläggande är att tron får sitt sanna uttryck i människans egna språk och kultur.

Gs betoning av modersmålet, folkligheten och historien ligger nära denna modells syn, och dessa likheter är viktigare enligt min syn att se än de skillnader som Gs syn på »det levande ordet « innebär. Trots att $G$ har en tydlig precisering av den kristna identiteten genom denna syn så kan detta sägas hänga samman med den kultur i vilken han verkar. Det danska samhället var på 1800-talet genomsyrat av den kristna tron som en central del av dess kultur. Gs kulturanalys ser 
dock helt annorlunda ut än modellens vilket i hög grad också beror på den tids förhållanden som $\mathrm{G}$ levde i. G söker finna det han kallar Folkeaanden, det vill säga de uttryck som ett lokalt samhälle uppvisar i språk och kultur, och han gör detta genom att främst studera folkets mytologi och dess historia. Men även genom att se på den samtida situationen i Danmark. Detta blir kanske tydligast i Gs politiska verksamhet samt i Mands Minde föreläsningarna. I de senare föreläsningarna kommenterar $G$ dagsaktuella frågor, och där finns drag av både analys av samtiden och politiska ställningstaganden. ${ }^{14}$

En betydande skillnad till modellen finns i den inspiration $G$ hämtade från den kristna traditionen. Kyrkofäderna och speciellt Irenaeus hade stor betydelse tillsammans med Luther för Gs teologi. Dessutom fick han viktiga impulser från stora delar av kristenheten genom de psalmer han tolkade till danska, bl.a. från äldre anglo-saxisk poesi och från latin och grekiska. ${ }^{15}$ En sådan stark inriktning på den kristna traditionen finns inte $\mathrm{i}$ den antropologiska modellen.

Den växelverkan som enligt $G$ finns mellan det folkliga och det kristna kan även tolkas som ett uttryck för den sammankoppling som modellen gör mellan kulturen och tron. Denna växelverkan tillsammans med den positiva synen på människolivet har $G$ uttryckt $i$ en av hans mest kända dikter som jag här vill citera några rader ur:

»Menneske først og Christen saa/ Det er et Hoved-Stykke,/ Christendom vi for intet faae,/ Det er den pure Lykke,/ Men Lykke, som kun times den,/ Der alt i Grunden er Guds Ven/ Af Sandheds ædle Stamme!

Stræbe de hver paa denne Jord/ Sandt Menneske at være,/ Aabne sit Øre for Sandheds Ord/ Og unde Gud sin ÆEre;/ Er Christendom da Sandheds Sag/ Om Christen ei han er i Dag,/ Han bliver det i Morgen. $\ll^{16}$

I dikten skildrar $G$ vägen till kristen tro genom att vara sann människa, att vara Guds vän handlar mer om att hålla sig till sanningen $i$ allmänmänsklig mening än om att kalla sig kristen. Sanningen är samtidigt en bild för Gud själv som han har uppenbarat sig i Kristus, sanningens Ord kan både stå för Johannesprologens Logos och för »det levande ordet«. I diktens mångtydiga form finns här en beskrivning av Gs syn på det komplexa förhållandet mellan det skapelsegivna människolivet och det kristna livet i kyrkan. Det är en 
växelverkan med ömsesidig påverkan där människolivet (kulturen) bl. a. ger förståelse och ord till det kristna som i sin tur befriar människan i kulturen till att allt mer leva sant mänskligt.

Om man till detta lägger Gs betoning av skapelsen, inte minst vad gäller människosynen och hans positiva hållning till skapelsen blir likheterna ännu tydligare till den antropologiska modellen.

\section{Är Grundtvigs teologi kontextuell enligt denna modell?}

G ligger enligt min tolkning mycket nära den antropologiska modellen för kontextuell teologi. Den enda punkten jag har funnit som skiljer dem åt är Gs betydelsefulla anknytning till den kristna traditionen och hans placering av »det levande ordet « $\mathrm{i}$ teologins centrum. Men då den kristna traditionen kan ses som en viktig del av kulturen i det danska samhället vid Gs tid är skillnaderna mycket små. Jag bedömer det alltså så att Gs teologi verkligen är kontextuell enligt denna modell.

\section{Modell 3: Praxismodellen}

Utifrån föregående modell finns alltid en tendens till eller risk för att teologin blir konservativ genom det starka bejakandet av människolivet som det levs $\mathrm{i}$ den rådande kulturen och genom att denna kultur bedöms vara god. Detta kan leda till en motsättning mellan den antropologiska modellen och praxismodellen.

Denna modell har nämligen sociala förändringar och reflekterad handling som sitt centrum. Genom handling förändrar man kulturen och får en fördjupad insikt $\mathrm{i}$ vem Gud är. Genom handling och reflektion i ljuset av skrift och tradition som upprepas i en slags hermeneutisk spiralrörelse når man till en allt mer kontextuell teologi.

Men denna motsättning mellan modellerna behöver inte vara fallet. Danmark var under 1800-talet på många sätt stadd i en stor förändring. Frågan är alltså om en antropologiskt kontextuell teologi under sådana förutsättningar samtidigt kan vara praxis-orienterad? 


\section{Den kristna trons identitet}

I denna modell utgörs den kristna trons identitet av ett sätt att handla och tänka snarare än enbart av ett sätt att tänka. Ortopraxis - rätt handling, är en term som använts i den latinamerikanska befrielseteologin för det som konstituerar denna form av kontextuell teologi. ${ }^{17}$ Detta begrepp ska inte förstås så att reflektion utesluts, utan det rör en kombination av handling och intellektuell bearbetning med hjälp av skrift och tradition. Identiten består av båda dessa sidor, men under förutsättning av att handlingen och reflektionen stämmer överens med Kristi befriande handlingar och ord.

Gs teologi skiljer sig mycket från denna modell, men det finns några likheter som kan vara av intresse att belysa. G skiljer mellan en kristen åskådning och en kristen tro. Den kristna åskådningen består främst av en världsåskådning som innehåller en kristen skapelsesyn och människosyn. Den kristna tron däremot innebär ett engagemang som i kyrkan tar sig uttryck i trons bekännelse, predikan och lovsång och som i hela utformningen av livet blir till tro, hopp och kärlek. ${ }^{18}$

Denna tro är hos $\mathrm{G}$ inte något statiskt utan befinner sig i tillväxt hos människan till en allt större likhet med Kristus själv. I denna växande tro finns handlingen med som en viktig del. G hävdar att handlingar som sådana är tvetydiga och inte kan vara tecken på en sann kristen tro, men då de sker i förbindelse med trons bekännelse, predikan och lovsången är de tecken på en sann kristen tro, eller som G skriver: »christelige Livstegn «. ${ }^{19}$ Utifrån Gs tänkande som jag har uppfattat det är dessa handligar oftast av helt annat slag än dem som förespråkas i praxismodellen. G är t.ex. mycket negativ till alla typer av revolution, även om han vill se en förändring av det rådande samhället på alla dess plan. Utifrån detta kan vi se att Gs teologi, trots skillnaderna mot praxismodellen inte innebär ett förnekande av handling eller samhällsförändring, även om de till viss del ser annorlunda ut mot modellens.

\section{Kulturen}

Bevans hävdar att det inom praxismodellen finns en grundläggande positiv hållning till kulturen. Den ses som starkt föränderlig och bärande möjligheter till att omvandlas till att ge människor frihet och 
goda livsmöjligheter. Detta kunde nästan ordagrannt sägas om Gs positiva syn på kulturen, med förbehåll för vad som ovan sagts om Gs syn på revolutionen. De metoder för samhällsförändring som $G$ föredrar handlar främst om utbildning, något som kan ses i samband med hans skoltankar. ${ }^{20}$ Men i Gs politiska arbete använder han andra metoder för att förändra samhället, det är framförallt genom debatt $\mathrm{i}$ tidskrifter och böcker men också genom tal i riksdagen, genom föreläsningsserier och tal vid olika folkliga samlingar. Även genom sina predikningar och sin psalm- och sångdiktning gör $\mathrm{G}$ inlägg i aktuella politiska frågor.

\section{Relationen mellan kristen tro och kultur}

Praxismodellen ser den kristna tron som ett gott redskap för sociala förändringar i kulturen, den kan alltså tillföra kulturen viktiga värden. Inte minst kan detta ske genom det engagemang som de kristna tillför gemenskapen då de sluter sig samman med andra i kamp för rättvisa och befrielse.

Den växelverkan som enligt $G$ bör råda mellan det folkliga och det kristna kan få liknande följder, även om det hos $G$ finns en annan syn vad gäller det kristnas påverkan på det folkliga. Hos $G$ kan det kristna tillföra syndernas förlåtelse och hoppet om ett evigt liv, samt ge språket ny kraft. Men han talar även om hur kristendomen kan befria människor och bidra till att tvång bekämpas. ${ }^{21}$ Men allt detta finns inom människans trosvärld och tankevärld och knappast som i vissa utformningar av praxismodellen i den politiska kampen för de fattiga.

\section{Är Grundtvigs teologi kontextuell enligt denna modell?}

Det är inte helt omöjligt att tolka Gs teologi som handlingsinriktad och syftande till sociala förändringar. G säger också uttryckligen att en människa inte kan förstå mer av den kristna tron och livet $\mathrm{i}$ allmänhet än vad hon själv har upplevt. Men det framgår inte klart hos $\mathrm{G}$ om denna upplevelse skulle kunna innebära en handling som kan identifieras med det som i denna modell kallas praxis. Det är alltså 
mycket tveksamt om G kan ses som kontextuell teolog enligt praxismodellen.

\section{Modell 4: Syntesmodellen}

Modellen vill ta hänsyn till alla möjliga faktorer samtidigt, den vill infoga samtliga de tre ovanstående modellema och dessutom räkna med andra kulturer än den egna, ett huvudord är dialog. I denna modell finns det alltså en större betoning än i den antropologiska dels av skriften och den kristna traditionen, dels av handlingen i syfte att förbättra kulturen. Även här menar jag att det är möjligt att se stora likheter med Gs teologiska syn.

\section{Den kristna trons identitet och synen på kulturen}

I denna modell liksom i den antopologiska är den kristna trons identitet något svårfångad. Identiteten kan ses som en viss attityd eller hållning snarare än ett specificerat innehåll. Hållningen karakteriseras av den öppna dialogen mellan olika trostolkningar och olika kulturuttryck. Kanske är den bästa karakteristiken av den kristna trons identitet enligt denna modell ordet öppenhet. Denna öppenhet inför olika nya och traditionella synsätt $\mathrm{i}$ teologin och dessutom både inför den egna och andra kulturer gör att det absolut inte kan finnas en överkulturellt given identitet. Alla teologiska uttryck ses därmed som lokala och tidsbundna, även de som finns i skrift och tradition. Det andra nyckelordet $\mathrm{i}$ denna teologi är dialog. Just i dialogen mellan alla de nämnda faktorerna kan den kontextuella teologin genom en pågående process gradvis utformas.

Vi såg i diskussionen om den antropologiska modellen att det hos $\mathrm{G}$ finns en betydande betoning av den kristna traditionen. Denna finns, inte bara genom att $G$ inspireras av bl.a. kyrkofäderna och genom hans psalmtolkningar, men också genom hela Gs syn på »det levande ordet «. Samtidigt betonar G olika typer av dialoger, som t.ex. det folkliga som står i växelverkan med det kristna. I Gs politiska tänkande finns också en stark betoning på att yttrandefriheten måste värnas så att det kan råda en fri diskussion i landet. En av grundprinciperna i Gs skoltankar är att undervisning och uppfostran ska 
ske genom en levande växelverkan mellan lärare och elever, det vill säga genom ett ömsesidigt samtal, eller en dialog.

Vi såg även under praxismodellen att Gs teologi inte är främmande för handling för förändring av samhället. Allt detta liknar hållningen som finns i syntesmodellen.

Den punkt som är mest åtskiljande mellan modellen och Gs syn är betoningen av dialogen med andra kulturer än den egna. $\mathrm{G}$ inspirerades starkt av de englandsresor han gjorde 1829, 1830, 1831 och 1843 och han höll sig informerad om händelserna och idéerna i omvärlden. Men när det kommer till hans skrifter om den kristna tron rör det sig om den danska folkligheten för G. Det är det egna folkets folklighet som främst måste främjas för att människor ska kunna ha möjlighet att ta ställning till den kristna tron. G levde i ett mycket homogent samhälle med ytterst få människor från andra kulturer och därmed betonade han ständigt vikten av den egna danska folkligheten och det danska språket.

En skillnad är även den tydliga identiteten som $G$ ger den kristna tron genom sin lära om »det levande ordet «, men jag vill här hänvisa till mitt resonemang under den antropologiska modellen. Om detta är hållbart behöver inte denna skillnad vara avgörande.

En annan slående kontrast är Gs kraftiga polemik och kritik mot vissa andra teologer och kyrkliga befattningshavare, och han tvekar inte att peka ut dem genom att nämna dem vid namn. Ofta kastar sig G över »skriftkloge« eller »boglærde« och »papister«, det vill säga de lutherskt ortodoxa teologerna och det katolska prästerskapet, som enligt $G$ vill ställa sig mellan människor och Gud. De ena genom läran och de andra genom den kyrkliga hierarkin. Den starka polemiken verkar vara något helt annat än den dialog som det talas om $\mathrm{i}$ modellen. Men i själva utformandet av sin teologi infogar $G$ förvånansvärt mycket från olika aktuella tankar. Ett exempel på detta finns i Gs människosyn. Människan är en helhet med tre olika egenskaper: föreställningsförmåga, känsla och förnuft. De första två kunde vilken romantisk filosof som helst hålla med om medan upplysningsfilosofens förnuft och upplysningsideal också finns med, detta sammankopplas sedan bl.a. med den bibliska tanken om människan som kropp, själ och ande och med Gs egen ordteologi. På liknande sätt kombinerar $\mathrm{G}$ olika rådande föreställningar med varann i ett slags synteser som blir självständiga originella nyskapelser. 
G står alltså $\mathrm{i}$ dialog med sin samtid och låter den få påverka honom i sitt utformande av teologin, detta skedde även i Gs upptäckt av »det levande ordet«. G har alltså enligt denna tolkning ett slags syntes-byggande i sin teologi där han kopplar samman olika delar av trosläran till helheter. G är knappast dialoginriktad i själva debatten, men när det kommer till praktiken finns det en betydande öppenhet till andras tankar och idéer.

\section{$\ddot{A r}$ Grundtvigs teologi kontextuell, enligt denna modell?}

Trots skillnaderna ligger Gs sätt att bygga sin teologi mycket nära den syntetiska modellen, den enda avgörande skillnaden är enligt mitt sätt att se den bristande dialogen med andra kulturer än den egna. Därmed anser jag att likheterna överväger.

\section{Modell 5: Den transcendentala modellen}

Denna modell har en historiskt och socialt formad enskild troende person och hans eller hennes religiösa upplevelse som centrum. Då denna upplevelse uttrycks på ett autentiskt sätt $\mathrm{i}$ de givna kulturella förhållandena sker kontextualiseringen. Modellen kan därmed kombineras med andra metoder för kontextualisering. Det vill säga om den person som gör kontextuell teologi utifrån en annan modell besitter de egenskaper som krävs enligt denna modell kommer kontextualiseringen att ske på två sätt samtidigt. Denna modell har den svagheten att den lätt kan tolkas som omfattande all teologi. Varje kristen människa som gör teologi, och som uttrycker den i sitt eget språk gör därmed kontextuell teologi. Modellen avgränsas genom en betoning av att teologen måste ha en djup förankring både i skrift och tradition och i den egna kulturen. Dessutom ska både erfarenheten av Gud och uttrycket för teologin vara autentiska. Om detta är fallet kan ses i effekten av den kontextuella teologin på det sättet att den är mer relevant i kulturen ju mer autentisk upplevelsen och uttrycket är.

Den effekt som Gs teologi och övriga tänkande har fătt i Danmark skulle enligt detta sätt att se vara ett tecken på en närmast total autenticitet. $G$ har som bekant inte bara haft ett brett inflytande i kyrkan eller på de många folkhögskolor som finns runt hela Dan- 
mark. I en artikel i boken »Stykkevis og delt« beskriver historikem Vagn Wåhlin vilken betydelse $G$ och hans efterföljare har haft på det danska samhället. Kyrkligt sett var effekten bl.a. att väckelserörelserna blev kvar inom Folkekirken, i skolorna finns inte bara en stor frihet $\mathrm{i}$ folkhögskolor eller privatskolor, även den allmänna skolan har långt större frihet än i Sverige eller Tyskland. På landsbygden växte det upp andelsmejerier och kooperation bland grundtvigianerna, W nämner energipolitiken och samlingshus för byalag eller kvartersboende, församlingshus runt hela landet och till och med Christiania i Köpenhamn. Bakom allt detta och liknande saker i Danmark ser Wåhlin en mentalitet som stämt med de intressen som funnits hos de dominerande klasserna i Danmark. Det vill säga med den självägande bondeklassen, något som har fått spridningseffekter i stora delar av befolkningen, och som alltså har viktiga delar av sitt ursprung hos $G$ och hans efterföljare. Till detta kan läggas den betydelse som Gs psalmer och sånger har haft och fortfarande har $\mathrm{i}$ hela den danska befolkningen, Wåhlin uttrycker detta i sin artikel:

»Kunne vi blot en enkelt dag løfte os op og lytte ud over landet fra barneskolen, over højskolen til kirker og alderdomshjem, da ville vi høre et brus af sang på denne dag som hver eneste dag året rundt. Fra vugge til grav ville tusinder af stemmer denne dag synge noget af Grundtvigs næsten ufatteligt store produktion af salmer og sange. $\ll^{22}$

\section{Den kristna trons identitet och kulturen}

Även i denna modell är det svårt att direkt peka ut något som kan ses som den kristna trons identitet. Modellen kretsar runt en religiös upplevelse som artikuleras på ett autentiskt sätt som nämnts. Men det finns en viktig koppling till bibeln i denna modell, det är nämligen skriftens ord, läst eller predikat tillsammans med den kulturella situationen som individen ska vara öppen för, först då kan hon erfara den gudomliga uppenbarelsen som ett möte, en relation eller ett skeende som hon är med om. Utifrån detta kopplas den kristna identiteten mer till bibeln än i några av de modeller vi sett tidigare, men det är inte skriften i sig som är det centrala utan den erfarenhet personen kan göra utifrån skriften och kulturen. 
För $\mathrm{G}$ är bibeln en upplysningsbok, en skrift som ger kunskap framförallt om »det levande ordet «, det som förutom att vara trosregeln för $G$ även är den plats där människor möter Gud. Detta sker framförallt vid gudstjänsten i kyrkan där de kristna livstecknen: trons bekännelse, predikan och lovsången sker. För $\mathrm{G}$ är alltså mötet med Gud mycket centralt liksom i denna modell, och detta möte sker genom den Heliga Ande som enligt $G$ »selv vil staae i levende VexelVirkning med Menigheden.... ${ }^{23}$

En skillnad är dock att $G$ i detta citat, som ofta i DCB, talar om församlingen snarare än om en kristen individ som modellen gör.

En likhet till som finns mellan $G$ och modellen är vidare betoningen av erfarenheten eller upplevelsen. $G$ skriver om detta i DCB bl.a. på följande sätt:

»Vel er nemlig paa det christelige Livs, som i det hele paa Menneske-Livets Vei giennem denne Verden, hvad Forstanden angaar, lyst bag og mørkt for, thi vi forstaaer aldrig mer af et Liv, end vi selv har oplevet, men paa det christelige Livs Vei skinner der dog et overordentligt og for saavidt overmenneskeligt Lys... $\ll^{24}$

Här talar $\mathrm{G}$ om möjligheten att förstå den kristna tron. Just som i det vardagliga livet kan vi inte se in i framtiden utan bara det som skett, och människan kan inte förstå mer än hon själv har varit med om. Men $G$ framhåller att kristna människor har ett ljus som även lyser upp framtiden, d.v.s. hoppet. Grundtvig-forskaren Svend Bjerg ser hela DCB som präglad av den transcendentala modellen. Bl.a. utifrån citatet ovan är det möjligt att motivera hans syn med Gs egna ord. Bjerg hävdar att Gs teologi bygger på hans egna livserfarenheter. Dessa erfarenheter som formulerats $i$ ord av $G$ leder till hans utformande av läran, det vill säga bl.a. det vi kan finna i DCB. Denna lära används sedan som tolkningsmall för nya livserfarenheter. Gs religiösa upplevelser berörs i ett flertal biografiska skildringar. Det är svårt att överskatta den betydelse som dessa upplevelser fått för Gs teologiska tänkande.

Kulturen behandlas inte i sig i denna modell utan den ses i relation till den teologiserande individen, denna person bör vara djupt förankrad i den egna kulturen för att hennes upplevelse eller erfarenhet av Gud ska kunna formuleras till en kontextuell teologi. 
Även vad det gäller denna punkt kan G ses som kontextuell enligt denna modell. Gs förankring i den danska kulturen blev djupt rotad i hans uppväxttid. ${ }^{25}$ Detta förstärktes av hans djupgående studier av den nordiska mytologin och historien och den närmast national-romantiska hållning som $G$ gjorde till sin. Ett uttryck för detta är tidskriften Danskeren som $G$ på egen hand gav ut under det s.k. treårskriget 1849-1851 där G skrev en rad fosterländska dikter och artiklar bl.a. om vikten av kärlek till fosterlandet.

\section{$\ddot{A r}$ Grundtvigs teologi kontextuell enligt denna modell?}

Om Bjergs tolkning av Gs teologiska metod är riktig, är Gs teologi ett typiskt uttryck för denna modell. Gs religiösa upplevelser hade stor betydelse för hans ställningstagande vad det gällde utformningen av den kristna läran. Han var också djupt förankrad i bibeln och traditionen och samtidigt i den egna kulturen. Detta sammantaget gör att jag vill hävda att $G$ kan tolkas som kontextuell teolog utifrån den transcendentala modellen.

\section{Sammanfattning och svar på problemställningen}

Vi har sett att Gs teologi på olika sätt stämmer överens med flera av modellerna för kontextuell teologi hos Bevans. Främst gäller detta den antropologiska och den transcendentala modellen. Det finns också viktiga likheter till den syntetiska modellen. Vissa av Gs verk kan också ses som uttryck för översättningsmodellen.

Denna breda överensstämmelse kan innebära en av två saker. Antingen att modellerna inte är användbara för att studera teologer av vissa (t.ex. västeuropeiska) slag och urskilja deras metod för kontextualisering, eller att Gs teologi har en ovanligt mångfasetterad kontextualitet. Modellerna är självfallet renodlingar som inte kan återfinnas $\mathrm{i}$ verkliga teologiska utformningar, men trots detta vill jag påstå att Bevans modeller har bidragit till att ge möjlighet att få syn på viktiga aspekter i Gs teologi. Bland dessa aspekter finns en stor öppenhet inför samtiden och den egna kulturen på flera olika sätt.

Svaret på min problemställning är utifrån dessa överväganden detta: 
Enligt min mening kan Gs teologi utifrån det ovanstående tolkas som en kontextuell teologi. Dessutom vill jag hävda att denna kontextualisering sker på ett flertal olika sätt samtidigt.

Avslutande kommentarer

Grundtvigs teologiska tänkande i den form den har hos $\mathrm{G}$ själv, kan av en rad skäl knappast användas för att uttrycka den kristna tron $\mathrm{i}$ en nordisk nutida kontext. Däremot kan den som vill utforma en kontextuell teologi i vår tid enligt min mening ha mycket att lära av Gs sätt att göra teologi. Dessutom finns det möjligheter att göra nytolkningar av Gs teologi som kan vara fruktbara, inte minst med koppling till Løgstrup. ${ }^{26}$

Jag vill lista upp några av dessa lärdomar, som $\mathrm{G}$ kan ge $\mathrm{i}$ utarbetande av en nutida kontextuell teologi, som en avslutning på min uppsats:

$1, G$ använder flera olika sätt samtidigt för att göra sin teologi kontextuell; $i$ vår tid med en ökad komplexitet bl.a. genom att samhället har en ökande mångfald i kulturen är detta enligt min mening en nödvändighet. En modern (eller postmodern) kontextuell nordisk teologi bör vara mångdimensionell och använda en rad olika metoder.

2, Något som underlättar det för $\mathrm{G}$ att vara kontextuell teolog är hans s.k. Kirkelige anskuelse, det vill säga den precisering av den kristna trons identitet som det jag ovan sammanfattat $\mathrm{i}$ begreppet »det levande ordet «. Identiten kan sammanfattas som en Kristuscentrerad treenighetsteologi, med betoning på skapelsetron i människosynen och av Anden i kyrkan. Den tydliga identiteten hos den kristna tron skapar möjligheter till en öppen hållning till kulturen utan oro för att förlora den kristna trons essentiella delar. Detta är också en nödvändighet för en modern kontextuell teologi, att finna en tydlig och avgränsad syn på den kristna trons identitet. Detta gör det bl.a. även möjligt för kyrkan att kunna släppa sin fixering vid sökandet efter sin identitet och istället kunna vara utåtvänd och öppen för kulturen. Den tydliga identiteten gör att kyrkan kan vara mer aktiv i samhällsdebatten på alla möjliga plan. 
3, Styrkan i Gs teologi är bl.a. det medvetna förhållningssätt som $\mathrm{G}$ har till sin omgivande kultur. Hela tänkandet kring det folkliga och det kristna visar på en genomarbetad syn på relationen mellan kristendom och kultur och en tydlig öppenhet för att låta kulturen få inflytande på både den kristna trons innehåll och dess uttryck. Det finns alltså en betydande öppenhet hos G för samhällsdebatt, de rådande tankarna inom filosofi, pedagogik och historietänkande, politiken och de historiska skeenden som skedde i Danmark. En sådan genomtänkt och öppen syn på relationen mellan kulturen och den kristna tron är nödvändig för att skapa någon form av kontextuell teologi även i vår tid.

4, En av hemligheterna med Gs enorma betydelse intill vår tid i det danska samhället är hans sånger och psalmer. Många danskar som knappast känner $\mathrm{G}$ mer än till namnet har sjungit hans sånger $\mathrm{i}$ skola och kyrka och på detta sätt fått del av hans teologi. Gs psalmdiktning var bl.a. ett genomtänkt och praktiskt sätt att göra kontextuell teologi i Gs tid. På detta sätt använde $\mathrm{G}$ sin tids uttryckssätt. Modern kontextuell teologi kan inte nöja sig med att skriva teologi, den måste finna andra nutida uttryckssätt som kan nå människor på olika sätt i vårt samhälle. Troligtvis är sång och psalm knappast det mest relevanta sättet i vår tid, även om de kan ha en viss betydelse i kyrkliga sammanhang. Men det finns en mängd andra kulturella uttryck som når människor $\mathrm{i}$ vår tid på olika sätt, problemet är att de så sällan bygger på människors egen delaktighet. Här behövs ett vidare studium av vår egen tid och den lokala kultur i vilken vi gör teologi.

\section{Noter}

Denna artikel är ett sammandrag av en s.k. D2 uppsats som framlades vid Teologiska institutionen i Uppsala. Ämnet var Kristen Trosåskådning inom området Tros- och Livsåskådningsvetenskap. Själva arbetet gjordes i Århus vid Center for Grundtvig-studier under våren 1995 under en mycket god handledning av forskningslektor Kim Arne Pedersen.

I själva uppsatsen görs en mer djupgående presentation av Bevans olika modeller för kontextuell teologi samt en längre genomgång av Grundtvigs 
teologi utifrån hans skrift »Den christelige Børnelardom" från 1868 samt några andra skrifter av Grundtvig. Jag utgår från att läsarna av Grundtvigstudier har en god kännedom om Grundtvig. Därför kommer jag här, av utrymmesskäl, att göra något svepande påståenden och antydningar om Grundtvigs syn på olika frågor. För källor och argument för min Grundtvig-tolkning hänvisas till själva uppsatsen.

2 Theodor Jørgensen gör detta i artiklarna»»Kierkens Gienmale « last $i$ et nutidigt perspektiv« i Grundtvig-studier 1992 och i »Kontekstuel teologi set $i$ sammanhang med Grundtvigs teologiska ansats" i Sigurd Bergmann och Carl-Reinhold Bråkenhielm (red): Kontextuell livstolkning, teologi i ett pluralistiskt Norden. Lund 1994.

3 Se t.ex. Per Frostins avhandling "Liberation Theology in Tanzania and South Africa, A First World Interpretation« Lund 1988.

4 Stephen B. Bevans: Models of Contextual Theology. New York 1992.

5 N.F.S. Grundtvig: Den Christelige Børnelardom i Georg Christensen och Hal Koch (utg): NFS Grundtvig Varker i Udvalg, band IV, Köpenhamn 1944. Alla sidhänvisningar till DCB i det följande gäller denna utgåva.

DCB skrevs som en rad essayer eller betraktelser under åren 1855-1861 och publicerades ursprungligen i tidskriften Kirkelig Samler vilken utgavs av Christian M. Kragballe. Betraktelserna sammanställdes i något ändrad ordning än i vilken de utkommit tidigare och utgavs $1868 \mathrm{i}$ bokform under titeln av den ursprungligen andra artikeln. Vid utgivandet lade $G$ till ett förord men gjorde i övrigt inga större förändringar.

För fler uppgifter om DCB, se:

Kaj Thaning: Menneske Først, Grundtvigs opgør med sig selv. Köpenhamn 1963. Band 3 s. 656.

Ernst J. Borup och F. Schrøder: Haandbog i N.F.S. Grundtvigs skrifter del 3: Kirkelige Grundtanker. Köpenhamn 1931. s. 135.

6 Bevans 1992 s. 1, kursiverat här.

7 Bevans 1992 s. 7.

8 DCB s. 20 och s. 239.

9 Se N.F.S. Grundtvig: Om Folkeligheden og Dr. Rudelbach. i Dansk Kirketidende nr 124, Köpenhamn den 30 jan 1848.

10 Se Lars Kaae: Ikkun som voxne Menneske-Bфrn: Grundtvig og frihed. i Bekker-Nielsen m.fl. Stykkevis og delt. Århus 1986. 
1 Se Regin Prenter: Den kirkelige anskuelse. En indførelse i N.F.S. Grundtvigs folkelige og kristelige grundtanker. Christiansfeld, 1983.

13 Jens Holger Schjørring har i artikeln Dogmatikkens hovedproblemer i Gregersen (red) Fragmenter af et spejl, Bidrag til dogmatikken, Frederiksberg 1992, påpekat att Grundtvig i sin psalmdiktning placerar in de bibliska berättelserna i den nordiska kontexten bl.a. genom scenskiften från den ursprungliga miljön till näraliggande välkända livssituationer.

14 N.F.S. Grundtvig: Mands Minde 1788-1838, Foredrag over det sidste halve Aarhundredes Historie. Köpenhamn 1871. se särskilt föreläsning nr XL från den 31 okt, s. 388-390.

15 Se Christian Thodberg och Anders Pontoppidan Thyssen (red): Grundtvig og grundtvigianismen i nyt lys. Århus 1983. s. $160 \mathrm{ff}$.

16 Citerad från Grundtvigs Sangvark del $3.2 \mathrm{nr} 156$ strof 7 och 8. utg. i Köpenhamn 1983.

17 Se Gustavo Gutierrez: A Theology of Liberation. New York 1973 s. 10.

18 DCB s. 92.

19 ibid.

20 Se N.F.S. Grundtvig: Skolen for Livet og Akademiet i Soer Borgerligt Betragtet. Köpenhamn1838. i Georg Christensen och Hal Koch (utg): NFS Grundtvig Værker i Udvalg, band IV, s 199-216. Köpenhamn 1943.

21 Grundtvig skriver bl.a. om detta i artikeln Folkelighed og Christendom i Dansk Kirketidende nr 107, 17 okt 1847. i Georg Christiansen och Hal Koch (utg): NFS Grundtvig Varker i Udvalg, band V Köpenhamn 1944, s. 243-251.

22 Vagn Wåhlin: Ikke stykkevis og delt i Bekker-Nielsen m.fl. Stykkevis og delt, 5 essays om Grundtvig og grundtvigianisme. Århus 1983. s. 9.

23 DCB s. 242.

24 DCB s. 93. 
25 Se t.ex. Steen Johansen och Henning Høirup (red): Grundtvigs Erindringer og Erindringer om Grundtvig. Andra utgåvan, Köpenhamn 1983. s. 59.

26 Kim Arne Pedersen: Grundtvig og teologien $i$ dag i Dansk Teologisk Tidsskift, årg 54. Köpenhamn 1991. s. 207. 